\title{
PALMITATE OR PERMANGANATE: THE VENEREAL PROPHYLAXIS DEBATE IN BRITAIN, 1916-1926
}

by

\section{S. M. TOMKINS *}

The early twentieth century saw a spate of activity in venereal disease research, with corresponding health policy implications. In 1913, when the word "syphilis" was first used with self-conscious daring in the lay press, there were virtually no treatment facilities for civilians in Britain. Five years later, there was a commitment to universal free treatment and an active public debate over the best means of prevention. Most of the historical attention to these developments has focused on this debate, which pitted the advocates of "medical" and "moral" prophylaxis against one another with increasing rancour. Indeed, many contemporaries complained that their mutual hostility distracted practical attention from the problem of venereal disease. Arguably, further attention to the prophylaxis debate perpetuates this distortion, especially when many other important topics, such as the fortunes of the new therapies and the organization of state clinics, are largely unchronicled.'

However, the prophylaxis issue merits further investigation for several reasons. First, in simplest terms there is a need for clarification, as the misleading claims and counter-claims by both sides have been reflected in the existing historiography. Notably, Bridget Towers' article, though valuable in many respects, misconstrues the essential issue which divided the two camps and is factually wrong on several key policy points. ${ }^{2}$ Secondly, the prophylaxis debate was the object of extensive contemporary media attention. Given this prominence, an accurate elucidation of the dispute deserves intrinsic examination. Furthermore, with its reflection of attitudes to medical developments and sexual morality, such a discussion forms the context of further research on related topics. Finally, it gradually became evident that, contrary to expectations, a treatment-based approach was not sufficient to prevent further infection (see below). In these circumstances, the fate of other preventive measures, especially chemical prophylaxis, was far more than an arcane point of dispute in the fight against one of the leading killer diseases of the period.

* S. M. Tomkins, Institute for the History and Philosophy of Science and Technology, Victoria College, University of Toronto, Ontario, Canada M5S IK7.

I would like to acknowledge the support of a Postdoctoral Fellowship from the Social Sciences and Humanities Research Council of Canada.

\footnotetext{
'A recent addition is David Evans, 'Tackling the "Hideous Scourge": the creation of the venereal disease treatment centres in early twentieth-century Britain', Soc. Hist. Med., 1992, 5: 413-33.

${ }^{2}$ Bridget A. Towers, 'Health education policy 1916-1926: venereal disease and the prophylaxis dilemma', Med. Hist., 1980, 24: 70-87.
} 
The purpose of this article is to reconstruct the debate between the advocates and opponents of chemical prophylaxis and to determine precisely what divided them. Contemporaries and historians alike generally perceived that "the two policies [were] indeed as widely separated as the poles", ${ }^{3}$ a view which the widely-publicized bitterness would seem to confirm. In fact, this paper will argue that very little indeed divided the two groups. In real policy terms, the debate hinged on the timing of the application of certain prophylactic chemicals. This intrinsically minor issue was invested with sufficient importance to draw out a public controversy which was increasingly embarrassing to both sides. Thus, the venereal prophylaxis debate was both less and more significant than recent historiography has suggested. The differences between the two groups were much narrower than Towers and others have assumed, but the very fact that these points of detail could generate such hostility reflects the assumptions and preoccupations of the period. These nuances are fascinating not least for their resonance to an age increasingly aware of the threat of sexually transmitted diseases.

\section{THE PARAMETERS OF THE PROBLEM}

Sir William Osler referred to syphilis as "third or fourth among the killing diseases, and first among the misery-causing diseases". The 1916 Royal Commission on Venereal Disease estimated that 10 per cent of Britain's urban population was infected with syphilis, and that the incidence of gonorrhoea was much higher. ${ }^{4}$ Congenital syphilis was widely viewed as a most tragic manifestation, with the sins of the parent literally visited upon innocent children. Syphilis was reported to be associated with a majority of cases of mental deficiency, epilepsy, heart disease in children, aortic disease, intrathoracic tumour, metritis, uterine haemorrhage, paroxysmal haemoglobinuria, interstitial keratitis, primary optic atrophy, and iritis, and was strongly correlated with ozena, nervous diseases, and choroiditis. ${ }^{5}$ Gonorrhoea was rarely fatal, but many contemporary observers believed that its impact was scarcely less grievous. ${ }^{6}$ It was more widespread than syphilis and more difficult to detect and cure, especially in women, in whom it was a major cause of infertility. Children were again particularly at risk, as passage through the birth canal of an infected women often resulted in blindness. With its toll in death and disability, and especially because of the hereditary character of syphilis, venereal disease was increasingly identified as a major factor in the physical deterioration of Britain's population. ${ }^{7}$

Although these high levels of mortality and misery were well known, treatment facilities were woefully inadequate. A Local Government Board report by R. W. Johnstone in 1913 noted that many hospitals refused to take any venereal cases, while those that did often incorporated a punitive element in their regimes. This approach was largely a measure of

\footnotetext{
${ }^{3}$ E. B. Turner, letter to Lancet, 1919, ii: 899.

${ }^{4}$ P.P. 1916, xvi, Cd. 8189, Royal Commission on Venereal Disease: Final report of the commissioners.

${ }^{5}$ Carl. H. Browning, 'Investigations on syphilis as affecting the health of the community', Br. med. J., 1914, i: 77-81; see also editorial, 'The syphilitic factor in some obscure diseases', ibid., 103-4.

'See, for example, C. J. MacAlister, 'The influences of venereal diseases', Br. med. J., 1913, ii: 1526-8; H. Wansey Bayly, 'The diagnosis and treatment of chronic gonorrhoea and its local complications', ibid., i: 584-6.

${ }^{7}$ See J. M. Winter, The Great War and the British people, London, Macmillan, 1986, ch. 1, regarding the concern over physical deterioration in early twentieth-century Britain.
} 


\section{S. M. Tomkins}

the stigma attached to the disease and the common belief that it was "self-inflicted"; indeed, charitable contributions to many hospitals carried the stipulation that funds could not be used to treat syphilis. ${ }^{8}$

In the first decade of the century, three medical developments offered potentially revolutionary changes in venereal disease therapy. In 1906, August Wassermann developed a reliable test for the detection of syphilis. In the same year, Elie Metchnikoff demonstrated that venereal infection could be arrested by the application of calomel ointment after exposure. Other chemicals were soon found to be effective, with permanganate of potash becoming the most popular. Disinfection was highly effective against syphilis, and Metchnikoff's disciples claimed some success against gonorrhoea. Finally, in 1910, Paul Ehrlich announced the discovery of a specific remedy for syphilis which was patented as "salvarsan". "Neo-salvarsan" was introduced in 1912 and had fewer serious side effects. None of these advances was fail-safe, and the problem of gonorrhoea remained largely untouched. The Wassermann test was complicated and expensive to perform, and was not a hundred per cent accurate. Disinfection was successful under laboratory conditions, but its practical application was more problematic. Administration of salvarsan was a complex procedure with significant risks of side effects. Moreover, despite early optimism that a single dose would suffice, a lengthy course of treatment was necessary before a complete cure was established. ${ }^{9}$ Nonetheless, these developments offered new methods of prevention and treatment against a disease which was serious enough even before the upheavals of the First World War.

The growing concern over physical deterioration joined with these therapeutic advances to stimulate interest and concern, first within the medical profession and gradually in the lay press. The call for a Royal Commission to investigate the problem was finally answered following an International Medical Congress in London in August 1913 where Ehrlich was the undisputed star. ${ }^{10}$ The Commission reported in 1916, and, in the meantime, the circumstances of war had exacerbated the situation which it had been appointed to consider. The most obvious concern was venereal disease in the armed forces, with much attention to

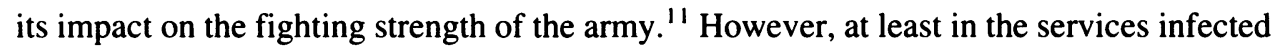
men were likely to receive prompt and thorough treatment, while venereal disease in the

\footnotetext{
${ }^{\star}$ P.P. 1913, xxxii, Cd. 7029, Local Government Board: 'Report on venereal diseases', by R. W. Johnstone,
} pp. 423-55

${ }^{9}$ For summaries of scientific developments regarding venereal disease, see J. Cassel, The secret plague: venereal disease in Canada 1838-1939, University of Toronto Press, 1987, chs. 2-3, and introductory material in A. Brandt, No magic bullet: a social history of venereal disease in the United States since 1880, Oxford University Press, 1985. See also L. Fleck, The genesis and development of a scientific fact, London, University of Chicago Press, 1979 (originally published in German in 1935), and indexed reference in the Br. med. J. and Lancet for contemporary accounts of the new discoveries and their reception in England.

" See editorials and correspondence in Br. med. J., 1913, ii: 194-5 and 269; Hospital, 26 July 1913, p. 500, 2 Aug. 1913, p. 518; Lancet, 1913, i: 1817-19; The Times, 6 Oct. 1913, p. 6; English Review, 1913, 15: 244; Pall Mall Gazette, 22 July 1913, p. 2; Observer, 10 Aug. 1913, p. 6; Daily Herald, 11 Aug. 1913, p. 3; Manchester Guardian, 11 Aug. 1913, p. 7; Daily Mail, 11 Aug. 1913, p. 4; Daily Telegraph, 27 July 1913, p. 4; Daily News, 15 Aug. 1913, p. 4; Daily Chronicle, 11 Aug. 1913, p. 5.

" See Edward H. Beardsley, 'Allied against sin: American and British responses to venereal disease in World War I', Med. Hist., 1976, 20: 189-202, and Suzann Buckley, 'The failure to resolve the problem of venereal disease among the troops in Britain during World War I', in Brian Bond and Ian Roy (eds), War and society: a learbook of military history, vol. 2, London, Croom Helm, 1977, pp. 65-85, for accounts of the military problem. The most vocal concern was expressed by political and military leaders from the Dominions, whose troops stationed in Britain and France experienced among the highest rates of infection. 
civilian population was nearly as serious and much more difficult to detect and control. ${ }^{12}$ With millions of men in uniform and large numbers of young women living independently for the first time, the perception of loosened sexual morals was universal. As venereal diseases were not notifiable, rates of infection were unknown but generally agreed to be escalating. It was well known that demobilization was usually accompanied by increased incidence of venereal disease, and it was feared that in this respect, as in so many others, the Great War would prove unprecedented in scope.

Not only were sexual contacts during the First World War perceived to be on a new scale, but they were also believed to be of a new and disturbing type. Whereas traditional anti-venereal policy had been directed at an identifiable sub-group of professional prostitutes, in wartime circumstances the focus of concern was the so-called "amateur prostitute" (or simply "amateur"). This revealing phrase referred to unmarried young women who freely indulged in sexual intercourse. While opinions on the motives of the "amateur" were divided, the policy implications of this distinction were clear: anti-venereal measures would have to be aimed at the general population. There was some dispute about whether soldiers represented a greater threat to women than women did to soldiers, but either way the prospect was serious. As the war progressed, there was a broad consensus that venereal disease was a grave social problem requiring immediate and vigorous attention.

\section{THE ORIGINS OF THE DEBATE}

Despite general agreement that the problem of venereal disease demanded speedy action, there was little unanimity on the direction or substance of anti-venereal policy and eventually these differences consumed the energies and hampered the activities of the reformers. The report of the Royal Commission requires only a summary here. ${ }^{13}$ Although it was appointed to consider all means of prevention and treatment and self-professedly approached its task from a strictly practical standpoint, the Commission's report made virtually no mention of Metchnikoff's work on disinfection. ${ }^{14}$ Its most distinguished medical member, Sir Frederick Mott, had wished to include some consideration of chemical prophylaxis, but eventually agreed to the wishes of the majority in the interest of securing a unanimous report. One observer remarked that the commissioners' silence with regard to disinfection

... was purposive, and attributable either to fear ... of a presumed hostility of 'Public Opinion', or to their prevailing disapproval of the spread of knowledge concerning the direct prevention of venereal infections by medical means. ${ }^{15}$

This view appeared to be justified by the later actions and pronouncements of some of the commissioners, particularly the chairman, Lord Sydenham (see below). In the event, the Commission made two main recommendations. First, clinics were to be established in each local authority jurisdiction to provide full and free facilities for the diagnosis and treatment

\footnotetext{
12 Letter to The Times from “M.D.”, 10 Jan. 1918, p. 10.

${ }^{13}$ See especially Richard Davenport-Hines, Sex, death and punishment, London, Collins, 1990, ch. 6.

${ }^{14}$ The success of Metchnikoff's experiments with apes was noted, with the comment that "this procedure has been shown to be also protective to man" but with no further elaboration. (P.P. 1916, xvi, Cd. 8189, p. 59.)

${ }^{15}$ Sir Bryan Donkin, 'The fight against venereal infection', Nineteenth Century and After, 1917, 82: 580-95. p. 585; Davenport-Hines, op. cit., note 13 above, p. 223.
} 


\section{S. M. Tomkins}

of venereal diseases (principally salvarsan for syphilis). As well as addressing existing levels of infection, this policy was also believed to be the most effective form of venereal prevention. By reducing the pool of carriers, opportunities for new infection would be correspondingly limited. ${ }^{16}$

The second part of the Royal Commission's plan outlined a public education campaign regarding the dangers of venereal disease and means of avoiding them. This task was delegated by the Local Government Board (replaced by the Ministry of Health in July 1919) to the National Council for Combatting Venereal Disease (NCCVD), which had been formed in 1914 but did not become active until the Commission reported. The NCCVD's executive included several members of the Commission, with Sydenham assuming the office of President, and received substantial public funds from the Local Government Board with virtually no scrutiny of its activities. ${ }^{17}$ The orientation of NCCVD propaganda was clear in its very name. A founding member recalled that "prevention" had originally been intended for the Council's title, but changed to "combatting" explicitly to "avoid suggesting that [medical] means should be taken to prevent infection". ${ }^{8}$ As Sydenham declared in the House of Lords, knowledge of preventive techniques "must tend to arouse a certain amount of curiosity and might, therefore, lead into vice men who would otherwise recoil from it". ${ }^{19}$ Council propaganda emphasized that "abstention from exposure to infection is the only certain safeguard ... continence is to be encouraged by every means and on every ground, both social and hygienic". ${ }^{20}$ Indeed, Council lecturers were explicitly forbidden to mention chemical disinfection. ${ }^{21}$ Since disinfection appeared to condone or even encourage illicit sexual activity, the only far-sighted and morally sound policy, according to the Council, was to treat the problem of sex, and not disease, as paramount. ${ }^{22}$

From the first, a number of physicians and other observers felt that the education campaign should include some mention of chemical prophylaxis. They tried for three years to work for change within the NCCVD, but with increasing frustration which culminated with a government report on venereal disease prophylaxis in August $1919 .^{23}$ Membership of the Committee did not include a single advocate of disinfection, and the orientation of its chairman, Lord Astor, was clear from his later fulminations on the subject. "I cannot imagine anything more revolting to fathers and mothers", he declared,

\footnotetext{
${ }^{16}$ E. Brown, 'The control of syphilis', National Review, 1919, 74: 105-11, p. 107.

${ }^{17}$ See Towers, op. cit., note 2 above, regarding the relationship between the NCCVD and Local Government Board/Ministry of Health.

${ }^{18}$ Sir Charters Symonds, letter to Lancet, 1919, ii: 1048; also cited in Davenport-Hines, op. cit., note 13 above, p. 231.

${ }^{19}$ House of Lords debates, 2 April 1919, col. 67.

20) NCCVD memorandum published in New Statesman, 29 Nov. 1919, p. 244.

21 'Venereal disinfection', by "Lens" (C. W. Saleeby), New Statesmen, 11 Oct. 1919, p. 31.

22 For examples of statements of the "moral approach" to venereal disease, by official NCCVD spokespersons and others, see Edmund Smith, 'The use of prophylactics in venereal disease', J. Roy. San. Inst., 1919, 40: 83-4; Hospital, I Dec. 1917, pp. 179-81, and 4 Jan. 1919, pp. 277-8; D. White, 'The prevention of venereal disease in theory and practice', Lancet, 1919, ii: 844-6; correspondence in Br. med. J., 1917, i: 243-4 and 278-80; and the series of articles by Sir Francis Champneys in Nineteenth Century and After, 1917-18.

2.3 P.P. 1919, xxx, Cmd. 322, Interdepartmental committee on infectious diseases in connection with demobilisation-Prophylaxis against venereal disease, pp. 427-52 (hereafter Astor report).
} 
that their sons and daughters should be taught how to indulge in promiscuous sexual intercourse with impunity... a combination of Hun material efficiency and Latin unchastity totally alien to Anglo-Saxon tradition and conscience. ${ }^{24}$

In the circumstances, the findings of the report were predictable. Astor concluded that "the true safeguard against these diseases is individual continence and a high standard of moral life", and emphatically advised against any recourse to medical prevention. ${ }^{25}$

Dissatisfaction with the report focused on two issues: the Committee's use of statistics (usually from military experience), and its narrow terms of reference. The experience of Portsmouth, where the prominent disinfection activist Sir Archdall Reid had been an army medical officer and had employed chemical disinfection systematically, became the focal point of the dispute. The Ministry of Health eventually admitted that the figures cited in the report as evidence of the failure of disinfection were "several times" too high. ${ }^{26}$ Later, Lieutenant-Colonel James W. Barrett of the Australian Army Medical Corps, who had directed medical services among Australian troops in Egypt, wrote to The Times from Melbourne to express his concern over the tactics of the Committee. The report stated explicitly that he had been invited to give evidence, and implied that its conclusions were significantly based on his experience. Barrett stated that not only had he never given evidence, but that he had never been invited to do so. His concern was that "the implication was given that the ... Committee had seriously and properly weighted the Egyptian evidence"- which strongly supported chemical disinfection. ${ }^{27}$ Nonetheless, long after the report was undermined by these revelations, the Ministry of Health and NCCVD continued to cite it as authoritative proof of the inadvisability of medical prevention. ${ }^{28}$

More fundamentally, the report's critics attacked its (self-imposed) terms of reference. ${ }^{29}$ The Committee's concern was restricted solely to whether the Government should officially endorse and supply "packets" to the civilian community. ${ }^{30}$ This term, which had arisen in the military, referred to a prophylactic kit (usually a tube of calomel ointment or a bottle of permanganate, and a cotton swab) to be carried in a pocket for the purpose of immediate self-disinfection following sexual intercourse. For the Committee to focus on the provision of packets was misleading and irrelevant, as advocates of disinfection desired only that the education campaign should include information on medical prevention, and that restrictions on the purchase of disinfectants should be removed (see below). This was one of a long series of such misapprehensions by the NCCVD and its supporters. To argue that their critics favoured issuing packets at the

${ }^{24}$ Sir Waldorf Astor, quoted in Davenport-Hines, op. cit., note 13 above, p. 238.

25 Astor report, p. 438.

26 The controversy over the Portsmouth statistics was traced in The Times and the Br. med. J., and culminated in P.P. 1919, xxxii, Cmd. 505, Statement of the Ministry of Health and the War Office regarding the incidence of venereal disease among soldiers in Portsmouth and elsewhere, pp.851-60; see also Sir G. Archdall Reid, The prevention of venereal disease, London, Heinemann, 1920, pp. 212-23, and letter to Br. med. J., 1920, i: 129, and letter to The Times, 10 Dec. 1921, p. 6; Bayly, letter to Br. med. J., 1921, i: 139-40; SPVD executive, letter to The Times, 11 May 1920, p. 18.

${ }^{27}$ Sir James Barrett to The Times, 21 Feb. 1922, p. 6, and 4 Aug. 1922, p. 10.

${ }^{28}$ C. Addison, quoted in The Times, 3 July 1920, p. 11; Viscount Peel, Lords Debate, 16 March 1921, col. 618-19.

29 See Donkin, 'Introduction' to Reid, op. cit., note 26 above, p. 13.

${ }^{30}$ Astor report, p. 429. 


\section{S. M. Tomkins}

taxpayers' expense to the tender youth of the nation, thereby providing both the suggestion and the security to engage in sexual relations without fear of consequences, became a favourite tactic. A typical propaganda statement in the Medical Times ${ }^{31}$ was headed "Why the National Council for Combatting Venereal Diseases Does Not Advocate the 'Packet", in heavy black letters when, after all, neither did its opponents.

The formation of the Venereal Prevention Committee in September 1919, and the full-fledged Society for the Prevention of Venereal Disease (SPVD) shortly afterwards, was the direct outcome of dissatisfaction with the Astor report and the conviction that it was hopeless to effect change from within the NCCVD. The memberships of the rival organizations were more striking for their similarities than their differences. Individual members' stances on venereal disease were rarely part of a consistent public health philosophy, and the issue attracted many elements of the "lunatic fringe". The most common strand in both groups was an interest in eugenics and racial purity, a concern which united the NCCVD President Sydenham and the SPVD's Secretary and most prominent spokesman, Hugh Wansey Bayly. The SPVD's President and voice in the House of Lords (where most of the parliamentary debates on venereal disease took place) was Lord Willoughby de Broke, but its most outspoken public advocates were the physicians Sir Bryan Donkin and Sir Archdall Reid (also a eugenist). ${ }^{32}$ Both groups were deeply concerned about the ravages of venereal disease and, as will be shown, were not seriously divided in objective policy terms. That the hostility between them escalated as it did was certainly due in part to personality conflicts. If Sydenham and others in the NCCVD persisted in misconstruing the "packet" issue, the abrasiveness of Bayly and Donkin must have been a factor in deteriorating relationships within the anti-venereal forces.

The SPVD sought to supplement, rather than to oppose or revise, the existing campaign against venereal disease. The SPVD strongly endorsed the liberal and free provision of clinics to encourage infected individuals to seek therapy. However, they argued that provision of treatment was not a sufficient means of prevention. Many victims continued to be sexually active after becoming infected, and a very high proportion failed to complete the regime before a cure was established. ${ }^{33}$ Thus it was necessary to look to other means to diminish the alarming incidence of new cases.

The SPVD also agreed that abstinence was both intrinsically desirable and the only absolute preventive of venereal disease, and that all propaganda should emphasize the virtues of chastity. However, to rely solely on moral suasion had two limitations. First, while all parties were agreed on the importance of maintaining and improving sexual morality, all were vague on how this utopian state was to be achieved. Many argued that sex education must begin early to be effective, while others objected that any mention of such matters to children would itself be an inherently corrupting and perverting influence. The Royal Commission recommended that instruction should not begin before the age of

\footnotetext{
${ }^{31}$ Med. Times, 1920, 48: v.

32 Sir Frederick Mott was also heavily involved in the SPVD but took little part in the public debate having been compromised by his accession to the Royal Commission report of 1916.

${ }^{3.3}$ Otto May, The prevention of venereal diseases, London, H. Frowle, Hodder \& Stoughton, 1918, ch. 2, 'Treatment in relation to prevention', p. 50; The Times medical correspondent, 13 Sept. 1920, p. 7, and 28 Feb. 1921, p. 10; 'The problem of venereal disease', Med. Times, 1920, 48: 53; Bayly, letter to Br. med. J., 1919, ii: 863.
} 
14 and left the matter up to individual school teachers, leading Reid to conjure up the image of

... a headmaster at the end of a term, ... expected to address [leaving boys] in words so eloquent and wise that they shall cast off immediately the effects of years of ribald training received during the most impressionable period of life, and ever after be proof against the temptations of the world. ${ }^{34}$

The precise content of sex education lectures and moral instruction rarely strayed beyond exhortations to vigorous outdoor sports and "clean living". Several observers warned against the danger of syphilophobia, or investing the disease with such horror and loathing that some victims would be too ashamed to seek treatment, or even be driven to suicide. ${ }^{35}$

Secondly, the SPVD contended that the prevailing incidence of venereal diseases itself proved that British mores were far from this ideal of chastity, and presumably a moral education approach would take a very long time indeed to effect any real improvement. In their view, the appalling toll of death and disability simply could not await the millenium. The SPVD disapproved of illicit sex as thoroughly as did the NCCVD, but believed that it must be accepted as a reality of contemporary social life. In these circumstances, the SPVD believed that all possible means must be used to combat venereal disease. If chemical disinfection could arrest its development, there were no defensible grounds for withholding this information. ${ }^{36}$ Diminution of disease, and not moral sensibility, was the crucial consideration. As Reid was wont to say in his standard Army venereal lecture, "I have talked to you [regarding chastity] until I am tired, and you still go wrong, but I will not have you bringing these beastly infections to barracks". 37

These convictions resulted in a three-fold platform. First, the SPVD, which was supported entirely by voluntary contributions, lobbied for a share of public funding on the grounds that the NCCVD represented only a narrow part of medical and public opinion. Secondly, it urged the Ministry of Health and the NCCVD to include information on disinfection as part of an integrated policy including clinics and sex education. Finally, it pressed for the removal of restrictions on the sale of chemical prophylactics in the Venereal Disease Act of 1917. This measure had been intended to abolish quackery in the treatment of venereal diseases by limiting all medical intervention to qualified practitioners, a goal heartily supported by the SPVD. However, one consequence was to restrict access to venereal disinfectants. While it was never illegal to sell such chemicals, chemists and manufacturers were forbidden to recommend them or to offer oral or written instructions for their use, even if specifically requested. In practice, access to and publicity regarding disinfectants were severely curtailed. ${ }^{38}$ The SPVD sought an amendment to overcome this obstacle while preserving the fundamental goal of the legislation. Thus, the

\footnotetext{
${ }^{34}$ Reid, op. cit., note 26 above, pp. 111-12.

${ }^{35}$ M. W. Browdy, 'The prevention of venereal diseases', Practitioner, 1922, 108: 142-6, p. 146; comment by A. Powell in discussion on syphilis, Proc. Roy: Soc Med., 1911-12, 5, p. 187.

${ }^{36}$ For statements of the SPVD position, see The Times medical correspondent, 11 Feb. 1921, p. 10; letter to Hospital, 14 Aug. 1920, p. 513, and 'Fighting disease by propaganda', 5 Feb. 1921, p. 429; Br. Imed. J., 1919, i: $125-7$ and $170-71$.

${ }^{37}$ Reid, 'Venereal disease', Nineteenth Century and After, 1921, 90: 348-60, p. 355.

${ }^{36}$ Davenport-Hines, op. cit., note 13 above, p. 229.
} 


\section{S. M. Tomkins}

new society aimed to give the individual full information and the opportunity to exercise his or her options regarding venereal prevention. ${ }^{39}$

The NCCVD opposed these proposals on both practical and moral grounds. It argued that the value of chemical disinfection was not proved; successful experience in the army was not necessarily applicable to civilian conditions. Furthermore, the circumstances under which illicit sexual contact often occurred, particularly involving drunkenness, militated against its efficacy. Indeed, by importing a false sense of security, publicity regarding disinfection might lead to more sexual activity and even higher levels of infection. ${ }^{40}$ To advertise sex as safe amounted to condoning, or even encouraging, vice, and the SPVD was seen to be deeply inconsistent in counselling continence on the one hand, and suggesting the means to indulge without fear on the other. ${ }^{41}$ Conversely, the fear of contracting venereal disease acted as a deterrent to illicit sex and therefore boosted public morality. The extreme conviction of some NCCVD members that any sanction of medical prevention was the thin end of the wedge of sexual licence was on record. In a highly publicized exchange with Donkin in The Nineteenth Century and After, the NCCVD Secretary Sir Francis Champneys stated that

... a person dying of syphilis innocently acquired is far better off than a person who commits either of these mortal sins [fornication and adultery] with complete physical safety and does not repent. ${ }^{42}$

In a letter to the New Statesman, another NCCVD stalwart declared that he would

... rather marry my daughter to a man suffering from venereal disease but pure in heart, than to a man whose idea of sex-relations were based upon and moulded by habitual indulgence in lust, even though he had contrived ... to avoid all unpleasant bodily consequences. ${ }^{43}$

Even granted that many venereal infections were "innocently acquired" (especially by women who were the victims of unfaithful husbands), the NCCVD believed that the prevailing high rates of disease were preferable to methods of prevention which publicized sexual knowledge.

\footnotetext{
${ }^{39}$ For statements of SPVD policy, see The Times, 3 Sept. 1921, p. 8; 27 Sept. 1919, p. 8; 6 Feb. 1920, p. 14; 13 Dec. 1921, p. 6, and 29 Feb. 1922, p. 8; see also a series of articles by Donkin and Hugh Elliott in Nineteenth Century and After, and columns by "Lens" in the New Statesman in 1919-1920, and Reid, op. cit., note 26 above (which was officially endorsed by the SPVD).

4) For the NCCVD's practical arguments against immediate disinfection, see Thomas Barlow to The Times, 6 Feb. 1919, p. 9; Addison, quoted in The Times, 3 July 1920, p. 11; correspondence in The Times, 29 Nov. 1921, p. 6, and 15 Dec. 1921, p. 8; E. B. Turner, 'The prevention of venereal diseases', Practitioner, 1922, 108: 30-9, pp. 30-7; White, op. cit., note 22 above; correspondence in the Br. med. J., 1917, i: 349-50; 1918, i: 208; 1919, i: 26; 1919, ii: 864 ; 1920 , i: $273-4$; 1921 , i: $66-7$.

4 ' For the NCCVD's moral arguments against immediate disinfection, see Brown, op. cit., note 16 above, p. 107; The Times, 4 June 1921, p. 7; C. J. MacAlister, 'Educational propaganda in relation to venereal diseases', J. Roy. Inst. Pub. Health, 1918, 26: 305-6; J. Roy. San. Inst., 1918, 39: 9, and 1919, 40: 91; and correspondence in the Br. med. J., 1916, i: 672; 1919, ii: 831; 1920, i: 29, 98-9 and 311; 1921, i: 66-7 and 246.

42 Champneys, 'The fight against venereal infection: a reply to Sir Bryan Donkin', Nineteenth Century and After, 1917, 82: 1044-54, p. 1050.

${ }^{+3}$ Gerald Maberley, letter to New Statesman, 8 Nov. 1919, p. 157.
} 
Once again, the NCCVD's attack centred on the so-called packet system. According to its opponents, the SPVD threatened to issue everyone (including impressionable boys and girls) with free or heavily subsidized packets, which was tantamount to providing the means to sin with impunity at the taxpayer's expense. "One can imagine", wrote a Bootle physician, "the feelings of a father whose son had been presented at school with one of those packets, and told it was human to err, and when they did err they might escape the consequences by using this". ${ }^{44}$ Opponents of disinfection were fond of quoting the American Navy Secretary Josephus Daniels to the effect that the mothers of America had

... entrusted [their sons] to my keeping with the strong belief that every good and Christian influence ... will be fostered and even strengthened ... could you expect me to place ... in the hands of these often absolutely innocent boys a 'preventive packet' and to say ... there is a possibility, or even the remotest probability, that they may need these 'preventives' while on liberty? ... I could not look a boy in the Navy straight in the face while I appealed to him to lead a clean life if I were approving the policy and the use of a measure of this kind. ${ }^{45}$

The most inflammatory claimed that "the way to the pit used in old days to be paved with good resolutions: it is now to be macadamized with prophylactic packets". ${ }^{46}$

The SPVD had never suggested that the Government should provide disinfectants; merely that it should allow access to them. Indeed, most members were positively opposed to the "packet system". Reid had criticized its introduction in the army, let alone in civilian life, ${ }^{47}$ and de Broke stated in the House of Lords that

I particularly wish to disclaim ... that I am here ... to recommend the free issue of what are called prophylactic packets, because I am strongly of the opinion, if any individual wishes to expose himself (or herself) to risk and at the same time chooses to take a disinfectant with him, that he ought to do so at his own expense and not at the expense of the general public. ${ }^{48}$

Every time an NCCVD-authored letter or article appeared with a misleading reference to the "packet system", the SPVD scrupulously followed it up with a correction and policy statement, but the accusations continued unabated. Bayly wrote in February 1921 that "... we have times without number pointed out that we do not advocate the packet system . .. and decline to accept the description of our policy as 'the issue of prophylactic packets to the civilian community". ${ }^{49}$ Following a Lords speech which never so much as mentioned the word and which was met with a chorus of outrage regarding packets, de Broke observed bemusedly that

${ }^{44}$ Dr Daley (Bootle), in J. Roy. San. Inst., 1918, 39: 6.

45 Josephus Daniels, quoted in Champneys, 'The fight against venereal infection: a further reply to Sir Bryan Donkin', Nineteenth Century and After, 1918, 83: 611-18, pp. 617-18; see also statement by the Archbishop of Canterbury, Lords debates, 10 Dec. 1919, col. 865-6.

${ }^{46}$ Anonymous letter to Br. med. J., 1920, i: 29. For additional examples of misleading references to packets in The Times correspondence alone, see 31 Dec. 1918, p. 9; 6 Feb. 1919, p. 9; 6 Oct. 1919, p. 6; 24 Nov. 1919, p. 10; 15 Nov. 1921, p. 14; 29 Nov. 1921, p. 6; 21 Feb. 1922, p. 6.

${ }^{47}$ Reid, op. cit., note 26 above, ch. 9 , 'Venereal disease in the army'.

${ }^{48}$ Lords Debates, 10 Dec. 1919, col. 842.

${ }^{49}$ Bayly, to Br. med. J., 1921, i: 247. 


\section{S. M. Tomkins}

I do not think in the speech I made I mentioned the words 'prophylactic packet' once... Words have been rather put into my mouth as if I had come down here to recommend a whole system by which people would stand at the street corners pressing prophylactic packets into the hands of passers-by, and providing them in a penny-in-theslot machine. ${ }^{50}$

This contemporary confusion regarding the aims of the SPVD accounts for the preoccupation (and inaccuracies) of historiographical attention with the "packet" issue. Towers states that the aim of the SPVD was "to promote the prohibited 'packet system", and that "the SPVD were quite explicit about the kind of propoganda and packet system they wished to promote ... Local authorities were to provide these packets which were to be made up of potassium permanganate and calomel ointment". ${ }^{51}$ In fact, from the very outset, this supposedly most contentious issue between the rival societies was a red herring. An examination of the evolution of NCCVD and SPVD policies from 1919-26 will reveal that their differences became even slighter as the hostile tone and rhetoric of the public debate escalated.

\section{THE EVOLVING DEBATE, 1919-1926}

As the chemical prophylaxis advocates gathered strength, the NCCVD gradually modified its position in response to a number of pressures. Although some distinguished medical authorities opposed chemical disinfection, the weight of scientific opinion favoured it, ${ }^{52}$ as did lay attitudes expressed in newspaper editorials and correspondence. The issue was less the utility of medical prevention per se, than the propriety of the NCCVD's withholding pertinent information from the public. It was widely agreed that a private interest group should not be able to curtail such access on the basis of a morality which did not necessarily reflect medical or general opinion, especially when it received substantial public funds. ${ }^{53}$ Finally, following the initial exodus to the SPVD, a steady trickle of defections and/or calls for moderation within the NCCVD continued. A founding member urged,

. . let the National Council pursue its advocacy of education and early treatment, without opposing the campaign of others who are out to attack disease and disease alone. If the National Council cannot bless, why should it curse? ${ }^{54}$

Finally, the success of the SPVD in attracting members caused the NCCVD to fear for its monopoly on public funding.

The NCCVD's first concession was to advocate ablution centres to offer "skilled" or "delayed" disinfection, beginning in early 1919. Although the Council had condoned

\footnotetext{
50 Lords debates, 2 April 1919, col. 93.

51 Towers, op. cit., note 2 above, p. 77, 80, 81 .

52 While there were many letters in the medical press from physicians opposing medical prevention, these tended to originate with and reiterate the views of a small group of NCCVD-affiliated physicians, especially E. B. Turner and Douglas White. There was, of course, a similar coterie of SPVD correspondents, but most of the "spontaneous" correspondence either rejected the NCCVD's restrictive approach to the dissemination of knowledge or positively favoured the SPVD position.

${ }^{53}$ The Times, leading article, 22 Nov. 1921, p. 11, and letter from Aylmer Maude, 12 Nov. 1921, p. 6.

${ }^{54}$ Symonds, letter to Lancet, 1919, ii: 1049.
} 
ablution centres in the military and never explicitly opposed them in civilian life, they were not actively promoted until self-disinfection was widely publicized, chiefly by Donkin. ${ }^{55}$ There were two advantages to such a policy. First, the procedure was performed by a trained attendant and was therefore more likely to be effective than self-disinfection. Secondly, the element of delay carried a crucial moral connotation. As Sydenham explained in the House of Lords,

I strongly feel that there is a distinct moral difference between telling people to go out with disinfecting packets in their pockets, and urging them, if they have fallen into temptation, to take the earliest possible treatment. ${ }^{56}$

The difference was between "making it easy and not making it easy for a man to yield to temptation". 57 Ablution centres were envisaged as a "safety net" for those who fell into unpremeditated $\sin$. Such individuals were to repair to the nearest centre as soon as possible after contact to abort the possible consequences of their rash acts. This distinction was reflected in the term "early treatment centres", which deliberately avoided the impression that the Council sanctioned prevention.

The SPVD argued in rebuttal that delayed disinfection was morally identical, but practically inferior, to immediate self-disinfection. To be effective, ablution centres must be numerous and their purpose widely and explicitly publicized. The provision of such facilities implied the same recognition and acceptance of illicit sexual activity for which the NCCVD condemned its rival. Ablution centres were also as likely to incite vice as self-disinfection, allowing a man (usually) to plan to indulge in sex safe in the knowledge that he could visit a nearby centre to avoid the consequences of his act. Indeed, as the Portsmouth Medical Officer of Health observed, the provison of ablution facilities was far more "suggestive" than merely offering advice to individuals. ${ }^{58}$ As de Broke stated in the Lords,

... some would seem to say that there is nothing really very immoral in going round to what is called an early treatment centre an hour or two after the connection has taken place; but that there is a difference between the morality of doing that and using certain disinfectants at the time of exposure to risk. I myself cannot see any great difference between these two processes. ${ }^{59}$

\section{A correspondent to The Times put it even more succinctly:}

If the critical hour is, say, 11 p.m., they object to the use of disinfectant at 10:45, but raise no objection if the treatment is used at 11:15. The sinner must not prepare for immorality, but he may use the best means known to science to escape the consequences. ${ }^{60}$

\footnotetext{
55 Although the SPVD was not formally inaugurated until December 1919, in the preceding three years there had been several well-publicized exchanges on the prophylaxis issue in The Times and elsewhere. Donkin precipitated several debates with letters on prophylaxis on 1 Jan. 1917 (p. 10), 4 Jan. 1918 (p. 5), and 28 Dec. 1918 (p. 7).

${ }^{56}$ Lords debates, 2 April 1919, col. 67.

57 Sir Malcolm Morris, 'Prophylaxis versus early preventive treatment', J. Roy. San. Inst., 1919, 40: 90-3, p. 91.

${ }^{58}$ A. Mearns Fraser, 'The prevention of venereal diseases', J. Roy. Inst. Pub. Health, 1921, 29: 17-25, pp. 22-3.

${ }^{59}$ Lords debates, 10 Dec. 1919, col. 852.

60) Anonymous letter to The Times, 4 January 1919, p. 7.
} 


\section{S. M. Tomkins}

Finally, ablution centres would entail considerable public expense. Given that the basis of the NCCVD's attack on the "packet system" was that taxpayers' money would go to mitigate the effects of sexual immorality, this irony was not lost on the SPVD, whose proposals required no government expenditure. ${ }^{61}$

While the element of delay imparted no moral benefits, it did reduce the likely effectiveness of the procedure. It was well known that the syphilis spirochete was fragile and easily destroyed while on the surface of the skin, but much more intractable once it had penetrated the tissues. While there was no precise consensus on how long the organism was vulnerable, clearly the sooner disinfectants were applied, the more likely they were to succeed. The SPVD also pointed out that many of the NCCVD's attacks on the efficacy of self-disinfection, particularly that illicit sex was often related to drunkenness, would equally discourage the responsible use of ablution facilities. To be at all effective, the centres must be prominent and well-publicized; yet, by the same token, would-be patrons might be reluctant to enter or to queue for service. Finally, no matter how liberally provided, ablution centres simply would not be convenient enough; even repentant sinners would be unlikely to go out of their way to reach the nearest facility. ${ }^{62}$ Indeed, most local authorities, including the London County Council, rejected the proposal as expensive and impractical. ${ }^{63}$ This was a severe blow to the NCCVD, which had conceded the principle of disinfection without securing its desired form.

A few months later, in a policy statement published in The Times and elsewhere, the NCCVD acknowledged that

... [any] person who has indulged in promiscuous intercourse . . is ... bound in duty to him (or her) self, and to society to seek means of cleansing at the earliest possible moment.

For this purpose a thorough local application of soap and water is of great value...

Soon, the Council allowed that stronger disinfectants were likely to be even more effective, ${ }^{64}$ but continued to oppose easier access to such chemicals. The SPVD argued that in encouraging the use of soap but opposing more effective chemicals, the NCCVD was again promoting a policy which was indistinguishable on moral grounds, but practically inferior to its own. As a prominent SPVD activist expostulated, "Palmitate [soap] is moral, permanganate immoral!"65 Furthermore, soap and water was messy and unlikely to be practical in the circumstances under which illicit intercourse often occurred (a great many such contacts were believed to take place out of doors). Sir Archdall Reid observed that the NCCVD felt it "wicked to provide disinfectants for immediate and

\footnotetext{
${ }^{61}$ For a sample of critiques of the morality of ablution centres, see Barrett, 'Venereal diseases in Egypt during the war', Proc. Roy. Soc. Med., 1918-19, 12: 10; 'The problem of venereal disease', Med. Times, 1920, 48: 53; Br. med. J., 1919, i: 125-7; May, op. cit., note 33 above, p. 102; Reid, op. cit., note 26 above, p. 6, and ch. 13, 'Civilian early treatment centres'.

${ }^{62}$ For a sample of critiques of ablution centres on practical grounds, see Bayly, 'The pharisaical ostrich', Med. Times, 1920, 48: 48; letters from Donkin and Reid, Lancet, 1919, ii: 945; May, op. cit., note 33 above, pp. 108-12; Reid, op. cit., note 26 above, p. 6, and ch. 13, 'Civilian early treatment centres'.

${ }^{6.3}$ Bayly, op. cit., note 62 above, p. 47.

${ }^{64}$ The Times, leading article, 8 Oct. 1919, p. 9, and letter from White, 24 Nov. 1919, p. 10; see also columns by Saleeby ("Lens") in New Statesman, 11 Oct. 1919, p. 31, and 29 Nov. 1919, p. 244; NCCVD policy statement, Br. med. J., 1921, i: 476.

65 Saleeby, 'Venereal disinfection', New Statesman, 11 Oct. 1919, p. 31.
} 
effective use, but permissible to provide... disinfectants for delayed and ineffective use". 66

From the beginning, the rival factions had been far more similar than dissimilar, and from this point their policy proposals were almost indistinguishable. In its concession of ablution centres and soap cleansing, the NCCVD had all but embraced the principles of self-disinfection. By 1921, the only distinctions between the SPVD and the NCCVD were the differences between palmitate and permanganate, and between the application of the latter at 10:45 or 11:15. Some individuals within the NCCVD acknowledged as much. One stated that

The N.C.C.V.D. have fundamentally moved from their original position to one which is practically shared by the S.P.V.D. Let this fact be honestly acknowledged, and let controversy lead to the amity of union. ${ }^{67}$

Sir Charters Symonds, who had been a co-founder of the NCCVD, agreed as early as December 1919 that "there is no difference in moral outlook at all, and it is wrong to charge those who advocate the logical outcome of our teaching with moral obliquity". 68 Strong elements within the NCCVD, however, remained unwilling to concede that there was any basis for rapprochement with the SPVD, asserting that anyone was "absolutely at fault if he considers that the policy of the [NCCVD] has in any way approximated to that of the [SPVD] ..." ${ }^{69}$ Although the policy stances of the two organizations had become virtually identical, the NCCVD continued to feel that there was a deep, if indefinable, difference between them which prohibited co-operation. The context of their proposals was crucial, maintaining a concern for a higher social morality vis à vis the SPVD's acceptance of illicit sexual activity. No doubt this impasse was partly a consequence of the Council's long-standing equation of self-disinfection with the encouragement of vice.

The end of the unseemly public wrangling of the rival societies finally came in 1923 with the report of the Trevethin Committee on "the best medical measures for preventing venereal disease in the civil community". ${ }^{70}$ The Committee was appointed at the suggestion of Lord Dawson of Penn, one of the most respected medical figures of the period. Dawson identified two essential issues in the debate over chemical disinfection: (1) its real efficacy; (2) its ethical justification. The former could be determined only by scientific specialists, and Dawson urged the appointment of an impartial expert committee to provide a definitive answer. If prevention were found to be practical, the ethical question of its implementation was not a medical preserve but a matter for a "wider tribunal of thoughtful public opinion". ${ }^{71}$ General satisfaction and confidence were expressed in the leadership and membership of the Committee, and the SPVD and NCCVD both expressed their willingness to co-operate. ${ }^{72}$

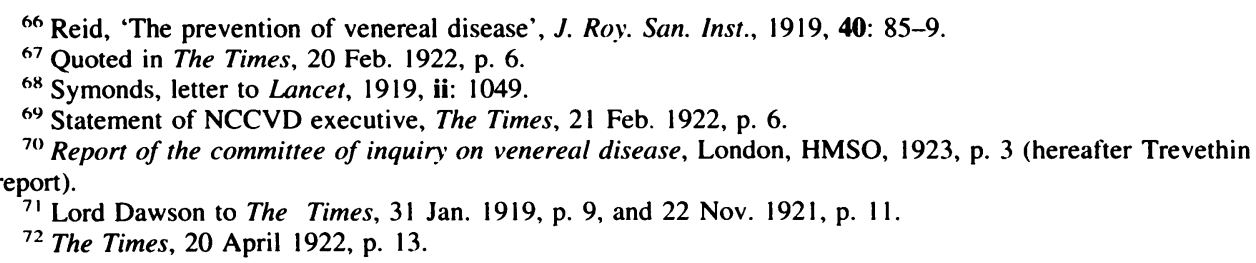




\section{S. M. Tomkins}

The Trevethin Committee presented its report in June 1923. The Committee acknowledged that self-disinfection was virtually a hundred per cent effective under laboratory conditions, but in practical application "the actual result is often less favourable than has been claimed". Furthermore,

...the success of any general facilities for self-disinfection is likely in the civil community to be very small ... our view is that money spent on a general system of providing facilities for self-disinfection would certainly be less profitable than money spent either on treatment of disease or on ... measures of education and improvement of social conditions. ${ }^{73}$

However, the SPVD had never claimed that disinfection was infallible; nor had they called for a costly "general system of providing facilities". Vis à vis its own stated policy objectives, the SPVD expressed itself well satisfied with the conclusions of the report, which stated that

... in view of the fact that disinfection in the case of an individual, if properly and promptly effected, will in all probability be successful, we do not think that there is any justification for putting obstacles in the way of individuals who desire to procure the necessary disinfectants ... we think the law should be altered so as to permit properly qualified chemists to sell ad hoc disinfectants. ${ }^{74}$

The NCCVD was mollified by the emphasis on treatment centres and education, and the two societies agreed to co-operate on the basis of the report. In the event, formal union never occurred, although by 1924 the respective offices of President were vested in the same individual, Sir Auckland Geddes, and the former rivals joined in urging the Ministry of Health to implement the recommendations of the report. ${ }^{75}$

To this point, the Ministry of Health has been mentioned only incidently, as it was content to give the NCCVD a free rein over the anti-venereal campaign as long as the latter shared its opposition to medical prevention. This stance was largely due to the influence of the first Minister of Health, Christopher Addison, and the long-time (1919-1935) Chief Medical Officer Sir George Newman. Newman admitted that disinfection was "practicable and effective" but persistently vetoed it on moral grounds. ${ }^{76}$ In large measure, this objection was based on continued misapprehensions regarding the SPVD's supposed advocacy of a "packet system", 77 despite the latter's repeated policy statements and requests for interviews at the Ministry to present their position. Even following the Trevethin report and the joint pressure of the NCCVD and SPVD to amend the Venereal Diseases Act regarding disinfection, the Ministry of Health refused to act. Several attempts by Sir Basil Peto, a Member of Parliament active in the SPVD, to achieve reform through a private member's bill failed. ${ }^{78}$ A ruling in 1925 did somewhat loosen restrictions on the sale of disinfectants by permitting chemists to furnish oral advice, but

${ }^{73}$ Trevethin report, pp. 6-7.

${ }^{74}$ Trevethin report, p. 6.

${ }^{75}$ The Times, 24 Aug. 1923, p. 8; 2 Nov. 1923, p. 9; 5 Mar. 1925, p. 11.

${ }^{76}$ Towers, op. cit., note 2 above, pp. 81-2.

77 Addison, quoted in The Times, 3 July 1920, p. 11.

${ }^{78}$ Commons debates, 16 June 1926, col. 2295-8; 3 Aug. 1926; 15 May 1928, col. 966-9. 
written instructions remained forbidden. ${ }^{79}$ Even with this latitude, the ambiguities of the legal position were such that many chemists were unlikely to act.

Towers concludes that the SPVD failed as a pressure group while the NCCVD enjoyed the favour of the Ministry and garnered all of the public funds available for anti-venereal work. However, in its early years the NCCVD was less a "pressure group" than an unofficial but heavily subsidized voice of Ministry views and policy. Once the path of the NCCVD diverged from that of the Ministry and towards the SPVD position, it equally failed to influence policy-making. That both societies failed as pressure groups after this point in their ultimate aim of influencing official policy was less a measure of their own merits than of the absolute opposition of the Ministry. Indeed, the NCCVD was ultimately the victim of its own success in creating an equation between the SPVD, venereal disinfection, "packets", and sexual immorality.

From the publication of the Trevethin report, public interest in venereal diseases gradually declined. No doubt sheer ennui was a factor, as was growing concern with Britain's other social and economic ills in the interwar period. Following the anticipated post-war high, rates of new infections began to drop, and although venereal diseases remained a major source of death and misery the sense of crisis which had characterized the late 1910 s and early 1920 s began to diminish. Finally, much public attention had centred less on venereal diseases themselves than on the melodrama of the public dispute between the SPVD and NCCVD. Once the wounds between the two societies began to heal, interest declined correspondingly. The SPVD continued to function throughout the interwar period, as did the NCCVD in its new guise as the British Social Hygiene Council from 1925, but neither would again enjoy the public attention which notoriety had brought in 1919-23.

\section{CONCLUSION}

In the hostility and subtleties of the prophylaxis debate, it is easy to lose sight of the remarkably rapid advances in venereal disease policy in World War I and the underlying changes in attitude which they signalled. Before World War I, syphilis was a taboo subject. Five years later, it was the first disease for which the British state provided universal free treatment. (The actual functioning of the new clinics is an important question as yet largely unexplored.) Although venereal prevention was not implemented, the free and (relatively) frank discussion of sexuality which it prompted constituted a veritable revolution in public discourse.

Yet, to the frustration of many contemporaries, much of this concern and energy was dissipated in the rivalry between the NCCVD and SPVD. Certainly, the tendency to hyperbole in both organizations fed the perception that they were widely divided on policy grounds. The SPVD painted themselves as the vanguard of scientific enlightenment and branded the NCCVD as moral terrorists who wished to maintain the hell of venereal disease as a means of deterrence. For their part, the NCCVD took the role of the upholders of basic social standards and portrayed the SPVD as inciters of random sex wishing to corrupt the nation's youth. Historical analysis of the prophylaxis issue has been informed (and often misinformed) by these terms. Closer examination reveals that there were

${ }^{79}$ Davenport-Hines, op. cit., note 13 above, p. 229. 
virtually no policy conflicts, and certainly no substantive ones, between the celebrated rivals. On the other hand, the fact that such minor differences could inflame such passions is all the more revealing of the assumptions and tactics of some powerful segments of opinion and policy-making. In their minds, the differences between palmitate and permanganate, and between disinfection at 10:45 p.m. and 11:15 p.m., were sufficient to tolerate the continued high incidence of a devastating and preventable disease. 